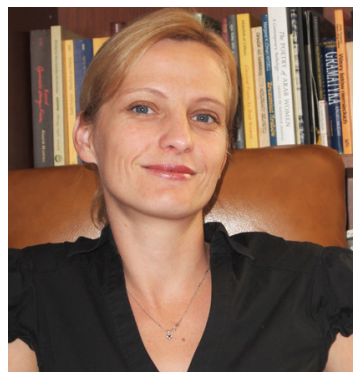

Magdalena Kubarek

Magdalena Kubarek - doktor nauk humanistycznych, absolwentka arabistyki w Instytucie Filologii Orientalnej Uniwersytetu Jagiellońskiego oraz studiów doktoranckich w Instytucie Orientalistycznym Uniwersytetu Warszawskiego. Jest autorką przekładów literatury arabskiej, artykułów i opracowań z zakresu arabistyki. Obecnie związana jest z Pracownią Języka i Kultury Arabskiej na UMK w Toruniu oraz Szkołą Języków Wschodnich na Uniwersytecie Warszawskim. Prowadzi badania w zakresie społecznych i kulturowych uwarunkowań rozwoju współczesnego świata arabskiego, współczesnej literatury arabskiej oraz interferencji międzykulturowych. Ważniejsze publikacje: Miraże i oazy. Su'ad as-Sabah i inne poetki arabskie (2006), W kręgu kultury islamu. Materiały dydaktyczne dla nauczycieli szkół ponadpodstawowych (z K. Górak-Sosnowską, 2007), Motyw śmierci w twórczości współczesnych poetek arabskich (2009) oraz tłumaczenia: Abd ar-Rahman Munif, Miasta soli (2010), Khalil Gibran, Połamane skrzydła (2012). 


\title{
Współczesna literatura muzułmańska w krajach arabskich
}

\author{
DOI: http://dx.doi.org/10.12775/LC.2014.002
}

iteratura muzułmańska (al-adab al-islami) jako część szeroko pojętej sztuki muzułmańskiej jest zjawiskiem stosunkowo nowym w świecie arabskim, lecz biorąc pod uwagę dynamikę jej rozwoju i skalę zasięgu, być może niedługo zyska rangę jednego z ważniejszych, jeśli nie dominujących nurtów, wyznaczających obowiązujące wzorce i kanony. Niemiecki badacz tego piśmiennictwa Johann Ch. Bürgel określa je jako najważniejszy i najbardziej zauważalny fenomen uwidaczniający się w literaturze krajów muzułmańskich od lat 80 . XX wieku1.

Popularyzacja pojęcia, a potem teorii literackich i samej literatury, wiąże się z działalnością Braci Muzułmanów oraz osobą głównego ideologa tego ruchu Sajjida Kutba (19061966) oraz jego brata, Muhammada (ur. 1919)². Pierwszym, który użył terminu „muzułmańskość” (al-islamijja), był Nadżib Al-Kajlani (1931-1995) w rozprawie Al-Islamijja wa-al-mazahib al-adabijja (Muzułmańskość i szkoły literackie) ${ }^{3}$.

Od lat 80. mamy do czynienia z coraz większą popularnością literatury określanej jako muzułmańska. Termin ten obejmuje wszystkie rodzaje piśmiennictwa: poezję, prozę i dramat. Szczególnie dużą popularnością cieszy się proza reprezentowana przez powieść (riwaja), opowiadanie (kissa), czyli gatunki, które zostały przejęte z Europy Zachodniej w XIX wieku.

Do rozpowszechniania w świecie arabskim nowej literatury, a szczególnie prozy, na której głównie koncentruje się ten artykuł, przyczyniła się działalność Światowej Ligi Literatury Muzułmańskiej (Rabitat al-Adab al-Islami al-Alamijja, International League of Is-

1 J. Ch. Bürgel, Der Islam im Spiegel zeitgenössischer Literatur islamischer Völker, [w:] Islam in der Gegenwart, red. W. Ende, U. Steinbach, G. Krüger, München 2005, s. 823-825.

2 Więcej na ten temat zob.: M. M. Dziekan, Die islamische Literathurteorie und-kritik von 'Imād ad-Dīn Halīl. Ein Vergleichendes Studium, "Rocznik Orientalistyczny“ 2009, t. LXII, z. 2, s. 16 oraz S. Hafez, The Novel, Politics and Islam, "New Left Review" 5, October 2000 (www.newleftreview.org/?view=2274; data dostępu: 15 | 2012).

${ }_{3}$ Odnośnie do sporu o początki użycia tego terminu oraz rozróżnienia pomiędzy teorią muzułmańskiej literatury, która powstała współcześnie a literaturą muzułmańską, tworzoną od czasu powstania islamu, do której zalicza Koran, hadisy, poezję mistyczną oraz zuhdijjat. Por. Dż. Al-Hamdawi, An-Nazaraijja al-islamijja fi al-adab wa-an-nakd, http://www.alukah.net/Literature_Language/0/39931/ (data dostępu 15 XII 2012). 
lamic Literature). Liga została założona w roku 1984. Jej powstanie i rosnąca popularność wpisywały się w ogólny nurt islamizacji życia społecznego, mającego swe źródła w sytuacji społeczno-politycznej regionu (klęska państw arabskich w wojnie z Izraelem w 1968, dewaluacja ideologii panarabskich i socjalistycznych, zwycięska rewolucja w Iranie). Założycielem i pierwszym prezesem Ligi był Hindus Alim Abu al-Hasan Nadwi (1914-1999). Nadwi wraz z Sajjidem Kutbem już w latach 40. i 50. XX wieku nawoływał do rozwoju literatury muzułmańskiej ${ }^{4}$. Do śmierci Nadwiego w 1999 roku siedziba organizacji mieściła się w indyjskim Lucknow. W 2000 została przeniesiona do stolicy Arabii Saudyjskiej. Obecnie prezesem Ligi jest jeden z jej założycieli, Abd al-Kuddus Abu Salih, literaturoznawca z Syrii.

Czym jest „współczesna literatura muzułmańska”? Co odróżnia ją od pozostałych nurtów i stanowi o jej odrębności? Po pierwsze „zaangażowanie” i jej związana z islamem perspektywa.

Jest to literatura zaangażowana (al-adab al-multazim), zaprzecza hasłom sztuki dla sztuki. Zresztą stanowi ona zjawisko marginalne w świecie arabskim. Nie tylko chodzi tutaj o Koran, niedościgły wzór literatury pięknej, oraz tradycję proroka (hadisy), na czym opierają się współcześni pisarze muzułmańscy. Zgodnie bowiem z zakorzenioną głęboko w kulturze arabskiej tradycją, wywodzącą się jeszcze z czasów plemiennych poetów, słowo zawsze miało zadanie do spełnienia - stąd nazwa beduińskich poematów: kasyda („poemat celowy”). Pierwotne znaczenie terminu adab (literatura) to „wychowanie”. Średniowieczna proza adabowa, której rolą było pouczanie i kształcenie, stała się niezwykle popularna za panowania Abbasydów (750-1258). Dzieła adabowe stanowiły swojego rodzaju niezbędne kompendia wiedzy dla wykształconego mieszkańca kalifatu abbasydzkiego z różnych dziedzin: filologii, retoryki, religii, filozofii, historii czy geografii.

Tradycja ta, kontynuowana była także w okresie odrodzenia arabskiego w XIX wieku, kiedy to pionierzy literatury arabskiej, adaptując zachodnie gatunki i style, obrali za cel wychowanie społeczeństwa, tworzenie nowej tożsamości i zagrzewanie do walki z kolonizatorem. W XX stuleciu literatura odgrywała rolę propagandową w istniejących reżimach, bądź była głosem opozycji.

Dla wspomnianego już Nadżiba Al-Kajlaniego literatura muzułmańska jest „literaturą odpowiedzialną" (masula), a odpowiedzialność oznacza zobowiązanie, które wypływa z serca i przekonań wierzącego, i które opiera się na Boskiej Księdze, zesłanej w jasnym języku Arabów"s.

Al-Kajlani podaje następujące cechy literatury muzułmańskiej:

- jest wyrazem artystycznym, pięknym i wzruszającym,

- ma swoje źródło w wierze,

- oddaje realia życia, człowieka, świata,

- opiera się na ideologicznych fundamentach islamu,

- porusza uczucia i wywołuje refleksje,

- wpływa na prezentowane postawy oraz wartości ${ }^{6}$.

Z kolei Liga na swojej oficjalnej stronie internetowej zamieściła następującą definicję literatury muzułmańskiej: „Islamic literature is the objective artistic expression of man, life

\footnotetext{
${ }^{4}$ M. M. Dziekan, op. cit., s. 16.

${ }^{5}$ Podaję za Dż. Al-Hamdawi, op. cit.

${ }^{6}$ N. al-Kajlani, Madchal ila al-adab al-islami, http://www.islamweb.net/newlibrary/display_umma.php?la ng=\&Babld=3\&Chapterld=3\&Bookld=214\&Catld=201\&startno=0. Data dostępu: 15 XII 2012.
} 
and universe from an Islamic perspective" (at-tabir al-fanni al-hadif an al-insan wa-al-hajat wa-al-kaun wufk at-tasawwur al-islami $)^{7}$.

Jednym z najbardziej uznanych teoretyków literatury muzułmańskiej jest Imad ad-Din Chalil (ur. 1939), wybitny współczesny intelektualista iracki, profesor uniwersytetu w Al-Mawsil, autor licznych opracowań z zakresu współczesnej myśli muzułmańskiej ${ }^{8}$, którego

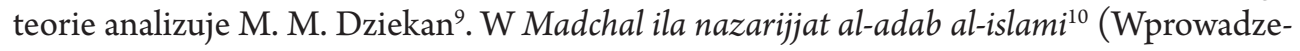
nie do teorii literatury muzułmańskiej) Chalil określa funkcje, które ma do spełnienia al-adab al-islami: najważniejszą i nadrzędną jest funkcja doktrynalna, następnie polityczna, społeczna, psychologiczna, historyczna, metodologiczna i wychowawcza.

Wyznacznikiem literatury muzułmańskiej dla Chalila jest więc nie tylko muzułmańska perspektywa i filozofia, ale również muzułmańska estetyka nawiązująca do wzorców koranicznych. Chalil podkreśla tym samym istnienie drugiego równoważnego kryterium definiowania literatury muzułmańskiej. Nie tylko treść, ale i forma jest jej ważnym wyznacznikiem. Jak pisze M. M. Dziekan, bez pięknej formy nie może być mowy o literaturze muzułmańskiej:

Wielu pisarzy uważało, i nadal żywi przekonanie, że temat jest jedynym kryterium dla muzułmańskiego charakteru literatury. To jest jednak zła droga [...]. Muzułmańska literatura nie ma być nieskomplikowaną literaturą poradnikową. Ona musi być także rzeczywiście „piękna”. Dla Chalila ta zasada wynika z Koranu ${ }^{11}$.

Chalil stara się więc zmierzyć z poglądem, że zaangażowanie literatury negatywnie wpływa na jej wartość estetyczną. Pogląd taki wydaje się dla muzułmanina zawierać w sobie sprzeczność. Wszak Koran jest niedościgłym wzorem literatury w języku arabskim.

W swojej rozprawie Chalil powołuje się na wersety 224-228 sury Poeci:

A jeśli chodzi o poetów,/ to postępują za nimi ci, którzy błądzą./ Czy ty nie widzisz,/ jak oni wędrują po wszystkich dolinach/ i jak mówią to, czego nie czynią?/ Wyjątek stanowią ci, którzy uwierzyli,/ pełnili dobre dzieła/ i często wspominali Boga./ Oni obronili się/ po tym jak doznali niesprawiedliwości./ A niebawem dowiedzą się/ ci, którzy czynili niesprawiedliwość,/ jakich przeciwności losu oni doznają! ${ }^{12}$.

Odnośny fragment według Chalila należy interpretować inaczej niż przyjęło się to w wykładni: powyższe wersety nie są skierowane przeciw poetom, natomiast potwierdzają prawdziwość i piękno poezji, która wywodzi się od Boga. Podobnego zdania jest inny uznany teoretyk sztuki i literatury muzułmańskiej Muhammad Kutb, dla którego literatura muzułmańska to: „piękny sposób wyrazu świata, życia, człowieka. Jest to sztuka, w której w sposób doskonały spotyka się piękno z prawdą. Piękno zaś jest prawdą istnienia, a prawda

\footnotetext{
7 Http://www.adabislami.org/English/whatis.html. Data dostępu: 15 XII 2012.

${ }^{8}$ I. ad-Din Chalil, Ruja islamijja fi qadaja mu'asira (Muzułmańska perspektywa we współczesnych problemach), Manama 1995, Fi al-fann at-taszkili wa-al-mumari (O sztuce i architekturze), Dimaszk-Bajrut 2007.

${ }_{9}^{9}$ M. M. Dziekan, op. cit., s. 15-25.

${ }^{10}$ I. ad-Din Chalil, Madchal ila nazarijjat al-adab al-islami, Dimaszk-Bajrut 2007.

11 M. M. Dziekan, op. cit., s. 18.

12 Koran, tłum. J. Bielawski, Warszawa 1986, s. 450.
} 
jest apogeum piękna. Stąd też spotykają się w opowiadaniu, w którym stykają się wszystkie prawdy istnienia"13.

Połączenie piękna i prawdy odróżnia literaturę muzułmańską od pozostałych nurtów obecnych w piśmiennictwie arabskim. Owa prawdziwość jest jej kolejną cechą dystynktywną. Zgodnie z postulatami Chalila al-adab al-islami powstaje z boskiej inspiracji, podczas gdy inne kierunki literackie czerpią z ludzkiego doświadczenia, dlatego też literatura muzułmańska jest odrębną formą i nie podlega tradycyjnej klasyfikacji ${ }^{14}$. Jej zaangażowanie nie jest związane z ideologią marksistowską ani socjalistyczną, jak znaczna część utworów prądu realistycznego, ani z egzystencjalizmem, do którego odnosi się większość utworów skupiających się na przeżyciach jednostki. Nie propaguje też idei kapitalistycznych, takich jak wolność jednostki i gromadzenia dóbr. Literatura muzulmańska opiera się na harmonii między wartościami duchowymi i materialnymi ${ }^{15}$.

Ostatnim wyróżnikiem literatury muzułmańskiej jest jej humanizm. Kryterium to jest sporne i nie wszyscy teoretycy i praktycy tej odmiany się z nim zgadzają. Wśród tych, którzy propagują pogląd, że istotę (dżauhar) perspektywy muzułmańskiej można odnaleźć także w działach pisanych przez niemuzułmańskich twórców, jest między innymi Muhammad Kutb (brat Sajjida Kutba), który w Madchal ila al-fann al-islami podaje przykłady takich utworów ${ }^{16}$. Podobnie na „muzułmańskość” literatury zapatruje się Imad ad-Din Chalil, który uważa, że wiąże się ona $\mathrm{z}$ uniwersalnością tej religii i jej humanistycznych wartości ${ }^{17}$.

Niezależnie od sporów teoretyków, termin „literatura muzułmańska” jest obecnie w powszechnym użyciu i coraz więcej utworów jest określanych tym mianem przez krytyków, wydawców, czytelników czy samych autorów. Działalność Ligi, której siedziba została przeniesiona do Arabii Saudyjskiej w dużej mierze przyczynia się do popularyzacji tego nurtu w świecie arabskim. Na stronie internetowej Ligi znajduje się motto, które w dużej mierze wyjaśnia przyczyny jej założenia oraz cele organizacji:

Zaprawdę obowiązek wezwania do Boga (ad-dawa) Wszechmogącego poprzez autentyczne i zaangażowane słowo oraz dążenie do umacniania literatury muzułmańskiej a także rozpowszechnienie fałszywej literatury w świecie arabskim i muzułmańskim skłoniło kilku pisarzy muzułmańskich do założenia Ligi. Ligi, która zewrze ich szeregi, podeprze każdego z nich ramieniem brata, wzmocni głos, wspomoże w obowiązku budowania podwalin literatury muzułmańskiej, krytyce literackich szkół na świecie oraz metod współczesnej krytyki, a także wyjaśnieniu tego, co w nich pozytywne, a co negatywne. ${ }^{18}$

Abstrahując od religijnego wymiaru działalności Ligi związanej z panislamistyczną ideologią, można powiedzieć, że cele przyświecające jej założycielom wykazują podobieństwo do założeń wszelkiego rodzaju stowarzyszeń literackich. Dla przykładu: Stowarzyszenie Apollo, które nawiązywało do panarabizmu i propagowało odrodzenie literatury arabskiej na początku XX wieku, zawarło w swoim statucie następujące postulaty: podnoszenie poziomu literackiego poezji arabskiej i zachęcanie poetów do szlachetnego współzawodnic-

\footnotetext{
13 M. Kutb, Manhadż al-fann al-islami, Al-Kahira 1960 , s. 6.

${ }^{14}$ M. Dziekan, op. cit., s. 20.

${ }^{15}$ Dż. al-Hamdawi, op. cit.

16 Ibidem.

17 Więcej na ten temat patrz: M. M. Dziekan, op. cit., s. 21.

$18 \mathrm{Http}$ ///adabislami.org/intro.html. Data dostępu: 15 XII 2012.
} 
twa, podtrzymywanie odrodzenia artystycznego w świecie poezji, dopomaganie poetom w rozwoju twórczym od strony materialnej i społecznej oraz obrona ich godności ${ }^{19}$.

Mimo różnic ideologicznych dzielących te dwie organizacje, zwraca uwagę zbieżność propagowanej przez nie idei solidarności twórców oraz odrodzenia literatury, choć Stowarzyszenie Apollo czerpało z wzorców europejskich, a Liga odrzuca je, uznając tego typu twórczość za fałszywą. Obie organizacje łączy również wydawanie własnych periodyków, na łamach których publikują swoje utwory ich członkowie.

Światowa Liga Literatury Muzułmańskiej wydaje publikacje w różnych językach: urdu, tureckim, angielskim. W języku arabskim ogłasza drukiem teksty „Al-Adab al-Islami” (Literatura Muzułmańska). Ostatnio ukazał się 75 numer tego periodyku poświęcony zmarłemu w 2012 roku pisarzowi, znawcy literatury arabskiej i poety, a także działaczowi Ligi dr. Dżabira al-Kumajhy. W wersji elektronicznej wydawana jest „Al-Madżalla Al-Iliktrunijja” (Magazyn Elektroniczny), której dotychczas powstało 20 zeszytów. Ostatni z nich, specjalny, również prezentuje dorobek i sylwetkę Al-Kumajhy.

Do promocyjnej działalności Ligi należy także przyznawanie nagród literackich w dziedzinie prozy. W 1993 dzieło Lan amuta sudan (Nie umrę na próżno) ${ }^{20}$ autorstwa Dżihad ar-Radżabi zdobyło pierwszą nagrodę w kategorii powieść, w pierwszym konkursie literackim organizowanym przez Ligę. Zgodnie z opisem publikacji na stronie Ligi utwór ten jest prawdziwym obrazem współczesnej walki w Palestynie ${ }^{21}$. Główny bohater, Wa’il, kocha swoją rodzinę i swój kraj, bierze udział w intifadzie. Nie widzi jednak sensu walki prowadzonej przy pomocy kamieni, podczas gdy żołnierze izraelscy strzelają do palestyńskich dzieci prawdziwymi kulami. Uważa, że należy żyć dla ojczyzny, a nie umierać dla niej. W końcu wyjeżdża do kraju marzeń, Ameryki. Jednak tęsknota za ojczyzną jest mocniejsza. Wa’il ucieka ze szpitala na lotnisko, aby wrócić do Palestyny. W chwili gdy właśnie zamierza wręczyć urzędnikowi trzymany w ręce bilet, dostaje zawału. Książka doczekała się kolejnych wznowień. Wydawca Maktabat al-Ubajkan reklamuje ją następująco: szybka akcja i zwroty wydarzeń sprawiają, że nie będziesz mógł oderwać się od lektury.

Autorka tej powieści jest Jordanką. Należy do Ligi i ma w swoim dorobku powieści Rahil (Odejście), As-Sahra (Pustynia), zbiory opowiadań m.in. Al-Jakin (Pewność), a także scenariusze. Za swoją twórczość otrzymała liczne nagrody w konkursach literackich ${ }^{22}$.

Drugą nagrodę literacką Ligi zdobyła powieść Al-A'ida (Powracająca) ${ }^{23}$. Jej autor Salam Ahmad Idrisu w 22 scenach, na które podzielił utwór, ukazuje problemy współczesnego pokolenia marokańskich nastolatków ${ }^{24}$. Jego bohaterowie stają przed trudnymi wyborami, między obowiązkiem a wolnością, tożsamością arabską a zachodnią, tradycyjnym społeczeństwem a nowoczesnym trybem życia. Główny bohater, sierota przygarnięty przez pobożnych ludzi, jest traktowany jak członek rodziny. Przestrzega w życiu zasad islamu, żyje otoczony miłością i szacunkiem. Jego celem i marzeniem jest ukończenie nauki. Natomiast bohaterka powieści reprezentuje młodzież, która myląc zepsucie z wolnością, uległa zgub-

19 J. Bielawski, K. Skarżyńska-Bocheńska, J. Jasińska, Nowa i współczesna literatura arabska 19 i 20 w. Literatura arabskiego Wschodu, Warszawa 1978, s. 268.

20 Dż. ar-Radżabi, Lan amuta sudan, Amman 1994.

21 Http://adabislami.org/إصدار ات_الر ابطة/il. Data dostępu: 15 XII 2012.

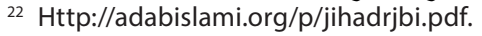

23 S. Idrisu, Al-A'ida, Amman, 1995.

24 Http://adabislami.org/إصدار ات_الر ابطة. Data dostępu:15 XII 2012. 
nym wpływom zachodniego świata. Nie jest ona jednak z natury zła, lecz po porostu pogubiła się i potrzebuje przewodnika, który wskaże jej drogę ${ }^{25}$.

O powieści $A l-A^{\prime} i d a$ wypowiada się w superlatywach w jednym z wywiadów w gazecie „Al-Watan As-Su’udi” (Saudyjska Ojczyzna) kuwejcka pisarka Lajla al-Usman. Określa ją jako jedną z najpiękniejszych książek, które czytała w ostatnim roku, a może nawet w całym życiu. Za największą wartość utworu uważa wierne odmalowanie realiów arabskich i problemów dzisiejszej młodzieży oraz przekaz pozytywnych wartości ${ }^{26}$.

Kolejna powieść Muchajjam, ja watan (Obóz dla uchodźców, ojczyzno!), która dostała drugą nagrodę literacką Ligi, także porusza problematykę palestyńską. Autor Dad Raszrasz an-Nasir rysuje koleją odsłonę cierpienia narodu palestyńskiego w obozach dla uchodźców. Opowiada historie tych, którzy wracają do ojczyzny po wielu latach życia na obczyźnie i muszą dokonać trudnego wyboru pomiędzy życiem w niedoli a pragnieniem dostatku i spokoju za cenę porzucenia bliskich, ziemi i ojczyzny ${ }^{27}$.

W kategorii „przekład” wyróżnienia otrzymują także powieści napisane w językach narodów muzułmańskich. Pierwszą nagrodą uhonorowano powieść pióra Alego Nara, sekretarza tureckiego biura Ligi, zatytułowaną Arilar ülkesi (Królestwo pszczół), przetłumaczoną na język arabski przez Ahmada Chawdża (Mamlakat an-nahl). Informacja na stronie Ligi określa Królestwo pszczól jako alegorię ojczyzny, która w wyniku wrogich spisków jest zagrożona, lecz ostatecznie udaje jej się wyzwolić i przegonić najeźdźcę ${ }^{28}$. Treść powieści Alego Nara omawia wspomniany wcześniej Johann Ch. Bürgel:

Na niezamieszkanej przez ludzi, pustej wyspie w Zatoce Perskiej żyją w przyjaźni pszczoły i mrówki. Ta idylla wzbudza jednak zawiść żyjących na sąsiedniej wyspie węży, które podstępem - oklejają ciała martwymi pszczołami - zdobywają wyspę, zyskują kontrolę nad owadami i je wykorzystują. W końcu jednak pszczoły budzą się z letargu. Potajemnie organizują olbrzymią armię pszczół, z których każda gotowa jest oddać życie w walce z wrogiem. Udaje im się pokonać i zmiażdżyć nieprzyjaciela oraz przywrócić stary nizam, boski porządek, który dla wierzących muzułmanów jest synonimem islamu i gwarancją życia w pokoju i sprawiedliwości ${ }^{29}$.

Kolejną kategorię, w której Liga przyznaje nagrody literackie, stanowią zbiory opowiadań. Do tej pory zostało wyróżnionych kilka pozycji. Wyróżnienie zdobył m.in. zbiór Fuha al-dżurh (Otwór rany) pióra Sukajny Kudur, zawierający 19 opowiadań. Akcja większości z nich rozgrywa się na algierskiej wsi. Autorka prezentuje barwny i realistyczny obraz społeczności wiejskiej, w tym życie algierskich kobiet, np. w tytułowym opowiadaniu Fuha al-dżurh czy opowiadaniu Ar-Rifija (Wieśniaczka). W opisie książki zamieszczonej na stronie Ligi możemy przeczytać, że język powieści wyróżnia „olśniewająca” poetyckość. Czytelnik w pewnym momencie orientuje się, że ma do czynienia z poezją, która ma i rytm, i rym, a jedynie zdania nie są podzielone na wersy ${ }^{30}$.

Nagrodę otrzymał także zbiór Al-Ard al-dżariha (Zraniona ziemia) autorstwa Surijji Ibrahim Marruszi, zawierający 20 opowiadań. Utwory dotyczą spraw ogólnoludzkich

${ }^{25} \mathrm{Http} / / /$ www.goodreads.com/book/show/3523986. Data dostępu:15 XII 2012.

${ }^{26} \mathrm{Http}: / /$ aprilmylove-lotus.blogspot.com/2010/04/blog-post_25.html.

27 Http://adabislami.org/إصدار ات_الرابطة-Data. Data dostępu: 15 XII 2012.

28 Http://adabislami.org/إصدارات_الرابطة-الرابطة-Data dostępu: 15 XII 2012.

29 J. Ch. Bürgel, op. cit., s. 824.

30 Http://adabislami.org/إصدار ات_الر ابطة-Data dostępu: 15 XII 2012. 
i społecznych. Akacja większości z nich rozgrywa się w Algierii, np. Saman al-chati’a (Cena błędu), Al-Ahlam al-mawuda (Żywcem pogrzebane marzenia), Al-Karja an-na'ima (Śpiąca wieś), Juriku al-amal (Kwitnie nadzieja), natomiast tytułowe opowiadanie „mówi o dramacie człowieka w ziemskim świecie" ${ }^{11}$.

Liga do tej pory nie przyznała nagród w kategorii liryki ani dramatu, choć zarówno pierwszy jak i drugi rodzaj literacki ma swoich uznanych przedstawicieli. Wiersze i sztuki teatralne poszczególnych autorów często wydawane są jako oddzielne publikacje lub ukazują się w periodykach Ligi.

Do zadań Ligi mających na celu popularyzację wiedzy o literaturze muzułmańskiej należy także organizowanie konferencji i kongresów. Ostatnia ogólnoświatowa konferencja odbyła się w dniach 23-24 kwietnia 2013 r. na Uniwersytecie Al al-Bajt (Jordania) ${ }^{32}$. Współorganizatorem konferencji było Centrum Studiów Świata Muzułmańskiego (Markaz Dirasat al-Alam al-Islami).

Oprócz Światowej Ligi Literatury Muzułmańskiej, centrum studiów i promocji literatury muzułmańskiej w Maroku i poza jego granicami stał się Uniwersytet Muhammada I w Wadżdzie ${ }^{33}$. Uniwersytet organizuje konferencje i wykłady poświęcone tej tematyce, które są prowadzone przez znanych teoretyków literatury. W Wadżdzie wydawane jest od 1983 czasopismo poświęcone literaturze muzułmańskiej „Madżallat al-Miszkat al-Maghribijja" (Maghrebijski Kaganek), na łamach którego ukazują się zarówno prace krytyczne, jak i dzieła pisarzy marokańskich ${ }^{34}$. Z tym ośrodkiem związani są tacy twórcy i badacze literatury, jak Muhammad Ali ar-Ribawi, Hasan Al-Amrani czy Abd Ar-Rahman Hautasz. $\mathrm{Z}$ centrum maghrebskim współpracuje wspomniany Dżamil Al-Hamdawi. W swoim studium poświęconym teorii muzułmańskiej, będącym wartościowym podsumowaniem historii współczesnej literatury muzułmańskiej, zebrał on nazwiska jej przedstawicieli oraz tytuły ważniejszych utworów. Dzieli je według następujących kategorii: proza (sardijjat), poezja (szir), sztuka teatralna (fann al-masrah), literatura dla dzieci (adab al-atfal), rozprawy krytyczne (an-nakd al-adabi) ${ }^{35}$. W obrębie prozy wyróżnia powieść, opowiadanie oraz krótkie opowiadanie. Za najważniejszych autorów powieści uważa: Nadżiba al-Kajlaniego $^{36}$, Alego Ahmada Bakasira autora As-Sar al-ahmar (Czerwona zemsta), Salama al-kass (Spokój księdza), Sira szudża (Biografia śmiałka) Al-Faris al-dżamil (Piękny rycerz), Lajla an-nahr (Noc rzeki), Auda al-musztak (Powrót stęsknionego), Imada ad-Din Chalila autora As-Sajf wa-al-kalima (Miecz i słowo), Farida al-Ansari autora Achir al-fursan (Ostatni rycerz) i Kaszf al-mahdżub (Odkrycie ukrytego), Ahmada Zurajka autora Bahsan an zill (Szukając cienia), Mustafę al-Dżabbariego autora At-Tarich jamzahu (Historia robi sobie żarty), Ramad al-chajma al-asza'irjja (Popioły plemiennego namiotu), Asz-Szajch wa-al-dżabal

\footnotetext{
31 Ibidem.

32 Odnośnie do szczegółów konferencji zob. http://www.aabu.edu.jo/adablslamy.pdf oraz http://adabislami.org/news/780. Data dostępu: 15 XII 2012.

33 Promocją literatury arabskiej zajmuje się także Al-Mahad al-Alami li-al-Fikr al-Islami założony w 1981 r. z siedzibą w Waszyngtonie. W 2007 Biuro Instytutu w Ammanie zorganizowało konferencję na temat literatury muzułmańskiej Al-Adab al-islami: At-Tasil wa-al-ibda (Literatura muzułmańska - genealogia i kreacja).

${ }^{34}$ Ibidem.

35 Niestety, w metodologii pisania prac stosowanej w krajach arabskich podawanie dat wydania utworów nie jest obowiązkowe. Ponieważ większość prac o literaturze muzułmańskiej jest autorstwa Arabów, dotarcie do danych bibliograficznych jest w dużym stopniu utrudnione. Dlatego też w niniejszym artykule bibliografia utworów jest fragmentaryczna. O problemach z dotarciem do danych pisze także M. M. Dziekan, op. cit., s. 22.

${ }^{36}$ Twórczość Nadżiba Al-Kajlaniego zostanie omówiona osobno w dalszej części artykułu.
} 
(Szajch i góry) Tukus al-mutaha (Zgubne rytuały) Al-Wadżh al-achar (Inna twarz), Salama Ahmada Idrisu autora Szadżara al-murid (Drzewo nowicjusza), Tauk an-naurus (Naszyjnik mewy), Al-A'ida (Powracająca), Al-Madaniego Adada autora Barid min zakira al-manfa (List od pamięci wygnania), Idrisa Al-Jazamiego autora Dżanna at-Tawarik (Raj Tuaregów) Abd al-Dżalila al-Wazzaniego autora Ad-Dufaf al-mutadżammada Tiksas (Zastygłe brzegi Teksasu), Ahmada al-Kariego autora La ahad jarifu ma uriduhu! (Nikt nie wie, czego chcę!) oraz Dżihad Ar-Radżabi autorkę Lan amuta suddan (Nie umrę na próżno) ${ }^{37}$.

Pośród twórców opowiadań Al-Hamdawi wymienia następujących autorów i ich dzieła: Nadżib Al-Kajlani, Imad ad-Din Chalil: Kalimat Allah (Słowo Boga), Rihlat as-su'ud allati la nihaja laha (Wspinaczka bez końca), Dżadwal al-hubb wa-al-jakin (Strumień miłości i pewności), Ibtihalat fi zaman al-ghurba (Błagalne modlitwy w czasie wygania), Abd Allah al-Kajsi Jam al-kura al-ardijja (Dzień kuli ziemskiej), Jusuf al-Burkadi Ahir al-miszkat (Ostatni kaganek), Abd al-Madżid Ibn Masud, Al-Achdud (Wąwóz), Ahmad Zurajk: Inna abakum kana ramijan (Wasz ojciec był strzelcem), Umm Salma: Ika'at fi qalb az-zaman (Rytmy w sercu czasu), Zilal Warifa (Długie cienie), Idris Al-Jazmani: Al-Dżidar (Ściana), Rahil al-launidża (Śmierć dozorcy), Muhammad Muntasir ar-Rajsuni: Al-Hubb fi Allah (Miłość w Bogu) Ahmad al-Aszhab: Hikayat Zajni ma an-nahar (Opowieść o Zajnim i rzece), Ahmad Zijadi: Chara'it bala bahr (Mapy bez morza) Szahid min harb al-basus (Świadek wojny Basusy), Szazaja (Odłamki), Al-Kalimat (Słowa), Wadżh fi al-maraja (Twarz w lustrach), Wala'im al-bahr (Uczty morza), Hasan al-Warakli: Ar-Rih wa-al-dżazwa (Wiatr i płonące polano), Al-Muchtar Lukman: Fi intizar al-fadżr (W oczekiwaniu świtu), Mustafa al-Dżabbari: Mazra an-nifajat (Plantacja odpadków), Nabila Azuzi: La tu'adni marratajni (Nie pogrzebiesz mnie żywcem dwa razy), Li-turab iszk achar (Ziemia ma inną miłość), Saliha Rahuti: Wamdat: Zakira al-ajjam ... minha wa-ilajha (Przebłyski pamięci dni... z niej i do niej).

W kategorii krótkie opowiadanie (qissa qasira dżiddan) Al-Hamdawi wymienia jedynie dwójkę pisarzy ze swojego ojczystego kraju, Maroka: Al-Husajna Zarruka i Wafę al-Hamri. Zarruk opublikował od 1996 cztery zbiory opowiadań: Al-Lajl wa-al-chajl (Noc i rumak), As-Surajm (Ugór) As-Salik (Droga) Al-Abradż (Wieże). Al-Hamri jest autorką zbioru opowiadań Bi-l-ahmar al-fani. Imra'at fi zaman al-harb (Wyblakłą czerwienią: Kobieta w czasach wojny).

Nazwiska prozaików często powtarzają się w innych kategoriach. Do autorów dramatów zaliczani są wspominani wcześniej Ali Ahmad Baksir i Imad ad-Din Chalil ${ }^{38}$. Co ciekawe, Al-Hamdawi podaje także szczegółową bibliografię wszystkich sztuk teatralnych, które ukazały się na łamach „Al-Madżalla al-Islamijja” wydawanej przez Ligę.

Dżamil al-Hamdawi nie określa kryteriów, na podstawie których dany pisarz zaliczany jest do twórców literatury muzułmańskiej, ani nie wartościuje ich dorobku. Należy jednak zwrócić uwagę na fakt, że za każdym razem nazwisko Nadżiba Al-Kajlaniego otwiera listę prozaików, a tuż za nim pojawia się Imad ad-Din Chalil.

Z kolei wspomniany wcześniej Chalil w Madchal ila nazarijjat al-adab al-islami jako najwybitniejszych współczesnych prozaików wymienia Nadżiba al-Kajlaniego i Muhammada al-Hasnawiego.

\footnotetext{
$37 \mathrm{Http} / / / w w w$. alukah.net/Publications_Competitions/0/39931/.

38 Ponieważ w swoim artykule koncentruję się na prozie, nie przytaczam nazwisk i tytułów poetów i dramatopisarzy. Wykaz nazwisk oraz tytułów zobacz: Dż. Al-Hamdawi.
} 


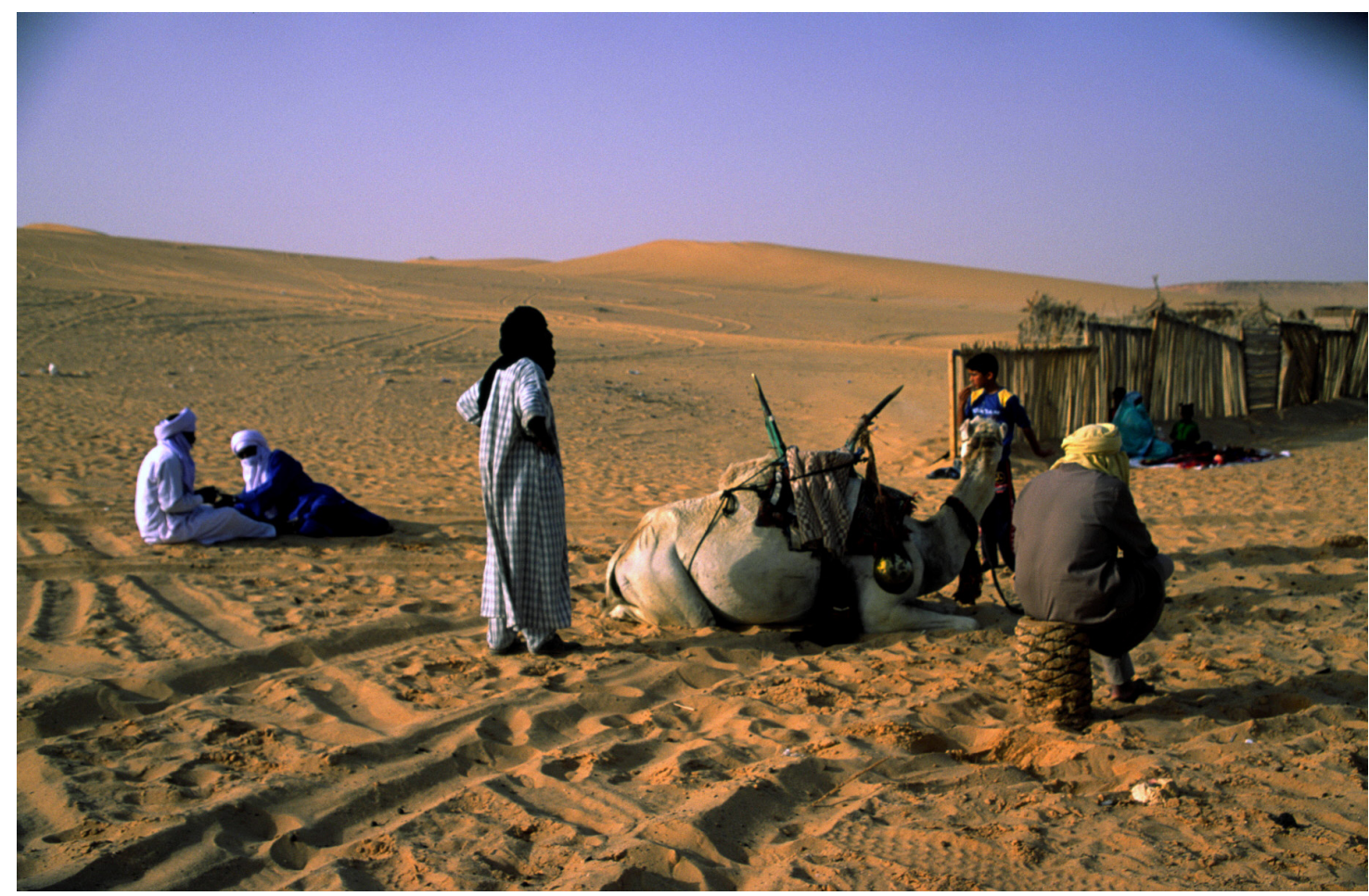

Grupa Tuaregów na Pustyni Libijskiej (fot. Z. Preisner)

Nadżib Al-Kajlani to człowiek-instytucja. Był zarówno pisarzem, poetą, jak i teoretykiem literatury muzułmańskiej ${ }^{39}$. Urodził się w 1931 roku w wiosce Szarszaba w zachodnim Egipcie. Jako pierworodny syn, zgodnie z tradycją przyjętą na egipskiej prowincji, został wysłany w wieku czterech lat na naukę do Kuttabu w rodzinnej wiosce. Tam nauczył się czytać, pisać, liczyć, poznał Koran oraz opowieści z życia proroka. Nauka w szkole nie zwalniała Al-Kajlaniego z obowiązku pomocy rodzicom w pracy w polu. Kontynuował edukację w szkole podstawowej we wsi Sinbad, a później średniej w Tancie. W 1951 roku wstąpił na Wydział Medycyny Uniwersytetu Kairskiego. Po ukończeniu studiów rozpoczął pracę w szpitalu w Gizie. Później pracował jako lekarz w rodzinnej wiosce, a następnie w Ministerstwie Transportu oraz na Wydziale Medycznym Kolei Egipskich. W 1968 wyjechał do Kuwejtu, gdzie pracował jako lekarz, ostatecznie osiedlił się w Zjednoczonych Emiratach Arabskich. W 1992 roku, na krótko przed śmiercią, powrócił do Egiptu.

Al-Kajlani już we wczesnej młodości zetknął się z ideologią Braci Muzułmanów. Uczęszczał na ich wykłady i - jak opisuje w swojej autobiografii Lamhat hajati (Szkic mojego życia $)^{40}$ - ukształtowały one jego światopogląd. W 1954 po nieudanym zamachu na życie Nasera zorganizowanym przez Bractwo nastąpiła fala aresztowań. Al-Kajlani po-

39 A. Abd al-Hamid, Nadżib al-Kajlani ra'id al-adab al-islami tanziran wa ibda'an. Lika ma'a ad-dukur Dżabir Kumajha, http://www.odabasham.net/show.php?sid=39613

40 Obszerna biografia pisarza składa się z 5 tomów. Tom pierwszy i drugi ukazały się w 1985, tom trzeci w 1988 oraz tom czwarty i piąty w 1994, czyli na rok przed śmiercią Al-Kajlaniego. 
czątkowo pomagał przy organizowaniu pomocy dla więźniów, a w rok później sam został aresztowany, postawiony przed sądem i skazany na dziesięć lat pozbawienia wolności za przynależność do tajnej organizacji zbrojnej. W 1958 roku, po trzech latach pobytu w więzieniu, został zwolniony z powodów zdrowotnych. Ponownie aresztowany w 1965, spędził $\mathrm{w}$ więzieniu kolejne dwa lata ${ }^{41}$. Prześladowania Bractwa utwierdziły Al-Kajlaniego w jego przekonaniach. Za kratami powstały wiersze, które następnie wydał w swoim pierwszym zbiorze poetyckim zatytułowanym Aghani al-ghurba (Pieśni obcych krajów). Tam także napisał pierwszą powieść: At-Tarik at-tawil (Długa droga), której akcję umieścił w dobrze sobie znanym środowisku wiejskim. Po ukazaniu się w 1960 r. powieść otrzymała nagrodę Ministerstwa Edukacji i Nauki oraz została umieszczona na liście lektur obowiązkowych dla uczniów szkól średnich ${ }^{42}$. O życiu w więzieniu opowiadają niektóre z jego powieści np. Nur Allah (Światło Boga) czy Al-Lajl wa-kudban (Noc i kraty).

Pisząc pierwsze powieści Al-Kajlani, jak sam wspomina, nie znał teorii literatury muzułmańskiej. Pisał po prostu z punktu widzenia prostego wieśniaka przywiązanego do tradycyjnych wartości islamu. Dużą inspirację twórczą stanowił dla niego poeta indyjski $\mathrm{Mu}-$ hammad Ikbal (1877-1938), który w pełnych żaru wersach krytykował ówczesny mu islam oraz wzywał do jego odnowy ${ }^{43}$.

Z czasem Al-Kajlani stał się jednym z najważniejszych teoretyków literatury muzułmańskiej. Niewątpliwie teorie literackie Al-Kajlaniego kształtowały się pod wpływem podglądów braci Sajjda i Muhammada Kutbów. Zawarł je w następujących rozprawach: Madchal ila al-adab al-islami (Wstęp do literatury muzułmańskiej), Ikbal asz-sza'ir as-sa'ir (Ikbal, poeta rewolucyjny,1971), Afak al-adab al-islami (Horyzonty literatury muzułmańskiej, 1985). Oprócz prac z zakresu literatury, opublikował także rozprawy o tematyce religijnej, politycznej i społecznej.

Al-Kajlani ma na swoim koncie ok. trzydziestu powieści, dłuższych nowel i zbiorów opowiadań. Napisał między innymi Katil Hamza (Zabójca Hamza), Ridżal wa-zi’ab (Mężczyźni i wilki), Hikajat Dżad Allah (Opowieść o Dżad Allahu), Mawakib al-ahrar (Pochody wolnych), Umar jazharu bi-al-Kuds (Umar pojawia się w Jerozolimie), Lajali Turkistan (Noce Tukistanu, 1974), Amalikat asz-szamal (Olbrzymy północy, 1974) Amirat al-dżabal (Księżniczka gór), Inda ar-rahil (Przy rozstaniu), Mawiduna ghadan (Jesteśmy umówieni na jutro), Ridżal Allah (Ludzie Boga), Faris Hauzan (Rycerz Hauzan), Hikajat tabib (Opowieści lekarza), Al-Kabus (Koszmar), Azra Dżakarta (Dziewica Dżakarty, 1974), Fi az-zalam (W ciemności, 1960). Jest autorem kilku zbiorów poetyckich oraz sztuk teatralnych. Charakterystyczną cechą prozy Al-Kajlaniego jest umieszczanie akcji w różnych krajach muzułmańskich (Chinach, Etiopii, Nigerii, Bośni Hercegowinie i Indonezji), co czyni ich przesłanie uniwersalnym. Nie dziwi więc fakt, że zostały one przetłumaczone na wiele języków, m.in. turecki, urdu, perski, indonezyjski, angielski, rosyjski oraz szwedzki. Co ciekawe, ten płodny pisarz i działacz Braci Muzułmanów unikał publikowania na łamach czasopism. Wolał wyrażać swoje poglądy w powieściach i pracach monograficznych ${ }^{44}$.

${ }^{41}$ Dż. Kumajha, Ma lamhat Nadżib al-Kajlani, http://www.odabasham.net/show.php?sid=29622. Data dostępu: 15 XII 2012.

42 Dż. as-Sajjid, Hiwar kabla ar-rahil, http://islamselect.net/mat/10567. Data dostępu: 15 XII 2012.

43 A. M. Dasuki, Nadżib al-Kajlani - Ra'id ar-riwaja al-islamija, http://www.ikhwanonline.com/new/Article. aspx?ArtID=65179\&SecID=0. Data dostępu: 15 XII 2012.

${ }^{44}$ A. al-Chatibi, Nadżib al-Kajlani - munazzir al-adab al-islami, http://www.najeebkelani.com/cv.php. 15 XII 2012. 
Nadżib Al-Kajlani zmarł 6 czerwca 1995 roku, po długiej i ciężkiej chorobie (cierpiał na raka wątroby). Do samego końca pozostał aktywny, przyjmując swój los z prawdziwą wiarą i pokorą ${ }^{45}$. Obecnie jest on najbardziej znanym twórcą literatury muzułmańskiej, a jego pisarstwo stało się wzorem dla kolejnych pokoleń pisarzy ${ }^{46}$.

Na stronie historycznej encyklopedii Stowarzyszenia Braci Muzułmanów (Al-Mawsu'a at-tarichijja ar-rasmijja li-Dżama'at al-Ichwan al-Muslimin) zaprezentowany jest następująco:

Niewielu jest świadomych celu, dla którego zostali stworzeni oraz rozumie naturę świata i jego stwórcy. Nie znajdziesz także wielu, którzy pojmują istotę życia oraz sposób, w jaki mają ją określać; zwłaszcza ci, co zdobyli nieco sławy w danej dziedzinie. Również nieliczni są ci, którzy pojęli sens istnienia, kroczyli drogą religii i potrafili kierować się w życiu wiarą, zarówno w realizacji zainteresowań, pracy jak i aktywności społecznej.

Dr Al-Kajlani jest jednym z tych, którzy zrozumieli ten cel. Okazał się on niezwykle utalentowany w sztuce tworzenia powieści, której nadał charakter muzułmański. Był wybitnym pisarzem. Dzięki swemu pisarstwu stał się ambasadorem islamu w większości krajów świat. ${ }^{47}$

Nawet ci, którzy nie zgadzali się z poglądami Al-Kajlaniego, jego orientacją polityczną czy teoriami literackimi, określali go jako człowieka niezwykle sprawiedliwego i ostrożnego w osądzaniu innych. Zdobywca nagrody Nobla, Nadżib Mahfuz, w wywiadzie dla periodyku „Al-Musawwar” (Ilustrowany) w październiku 1989 roku wychwalał jego szczerość i rzeczowość ${ }^{48}$. Z kolei założyciel wspomnianego Stowarzyszenia Apollo, Abbas al-Akkad, który bardzo ostro krytykował Braci Muzułmanów, określał Al-Kajlaniego jako człowieka przenikliwego, analitycznego, otwarcie deklarującego swoje poglądy ${ }^{49}$.

Drugi z wymienianych przez Imada ad-Din Chalila twórca, Muhammad al-Hasnawi jest określany mianem ar-riwa'i, asz-sza'ir, al-adib al-multazim (powieściopisarz, poeta, zaangażowany literat) ${ }^{50}$. Urodził się on w 1938 roku w małej miejscowości Dżisr asz-Szurur. Szkołę średnią ukończył w Latakii (Syria), gdzie zetknął się ideologią Braci Muzułmanów oraz zaczął pisać wiersze okolicznościowe z okazji świąt narodowych i religijnych. Kontynuował naukę na uniwersytecie w Damaszku. W 1962 otrzymał dyplom z pedagogiki i literatury arabskiej. Po zakończeniu studiów licencjackich pracował jako nauczyciel licealny w Aleppo (1962-1980) $)^{51}$. W tym czasie publikował wiersze i opowiadania w prasie oraz uzupełniał wykształcenie, uzyskując tytuł magistra na Uniwersytecie Libańskim.

Muhammad Al-Hasnawi jest przede wszystkim uznanym poetą i autorem kilku zbiorów poezji. Na swoim koncie ma także rozprawy naukowe m.in. Fi al-adab wa-al-adab al-islami (O literaturze i literaturze muzułmańskiej, 1986 ) Dirasat fi al-kissa wa-ar-riwaja $f i$ Bilad asz-Szam (Studia nad opowiadaniem i powieścią w Syrii, 2004) oraz Dirasat fi asz-szir

45 Ibidem.

${ }^{46}$ Analizy twórczości Al-Kajlaniego według kryteriów teorii muzułmańskiej prezentuje M. M. Dziekan, op. cit., s. 23-24.

${ }^{47}$ Al-Mausu'a at-tarichijja ar-rasmijja li-Dżama'at al-Ichwan al-Muslimin, http://www.ikhwanwiki.com. Data dostępu: 15 XII 2012.

${ }^{48} \mathrm{Http} / / /$ www.ikhwanonline.com/new/Article.aspx?ArtID=65179\&SecID=0. Data dostępu: 15 XII 2012.

49 Dż. Kumajha, Ma lamhat Nadżib al-Kajlani, http://www.odabasham.net/show.php?sid=29622. Data dostępu: 15 XII 2012.

${ }^{50}$ Al-Mausu'a at-tarichijja ar-rasmijja li-Dżama'at al-Ichwan al-Muslimin, http://www.ikhwanwiki.com. Data dostępu: 15 XII 2012.

51 Ma'a asz-sza'ir Muhammad Al-Hasnawi rahimahu Allah http://www.shababsyria.org/vb/showthread.ph

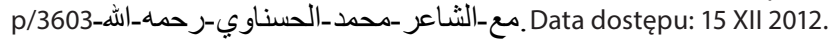


al-arabi kadimihi wa-hadisihi: ruja islamijja (Studia nad starą i nową poezją arabską - perspektywa muzułmańska, 2002) $)^{52}$.

Jako prozaik znany jest dzięki powieści Chutuwat fi al-lajl (Kroki nocą, 1994) Jej akcja rozgrywa się w Syrii w latach 80., czyli w okresie walki prezydenta Hafiza al-Asada z Braćmi Muzułmanami. Oprócz Chutuwat fi al-lajl autor napisał kilka zbiorów opowiadań: Al-Halba wa-al-mirat (Ring i lustro, 1972), Bajna al-kasr wa-al-kala (Pomiędzy zamkiem i twierdzą, 1988), Bilad an-nawabigh (Kraj geniuszy, 1999). Uważa się, że proza Al-Hasnawiego jest $\mathrm{w}$ dużej mierze oparta na faktach $\mathrm{z}$ biografii pisarza oraz nawiązuje do historii jego rodzinnej wsi i wydarzeń w ojczyźnie. Al-Hasnawi jest także twórcą literatury dla dzieci, które zawsze były dla niego bardzo ważnymi odbiorcami.

Z powodu swojego zaangażowania politycznego i przynależności do Braci Muzułmanów, pisarz przebywał w więzieniu i ostatecznie musiał opuścić Syrię. Na emigracji (m.in. w Paryżu i Londynie) aktywnie brał udział w dyskusji prowadzonej na łamach prasy, odnosząc się do aktualnej sytuacji w Syrii. Zmarł w 2007 roku w Ammanie.

Według danych ze strony Braci Muzułmanów Muhammad Al-Hasnawi był oświeconym intelektualistą muzułmańskim o szerokich horyzontach i doskonale znającym arabskie dziedzictwo kulturowe. Był miłośnikiem cywilizacji muzułmańskiej, który opanował sztukę wypowiadania się zarówno w poezji, jak i prozie. Nie przestawał tworzyć mimo bólu rozłąki z ojczyzną i choroby, nie zważając na kryzys książki i recesję na rynku wydawniczym. Pozostawił po sobie bogaty dorobek na najwyższym poziomie, obejmujący pozycje wydane oraz przygotowane do druku ${ }^{53}$.

Warto zwrócić uwagę na fakt, że literatura muzułmańska powstaje także poza granicami świata islamu, wszędzie tam, gdzie istnieją znaczące mniejszości muzułmańskie, ale także w takich krajach, jak Polska ${ }^{54}$. Do dzieł tego nurtu w językach europejskich należą ukazujące się w ostatnich latach powieści w Niemczech. Ich autorami są muzułmanie arabskiego lub tureckiego pochodzenia, albo konwertyci. Literatura ta skierowana jest w dużej mierze do młodego czytelnika i ma wybitnie moralizatorski charakter.

Za przykład tego typu dzieła może posłużyć powieść Noura, Sandry Abded, reklamowana jako „opowiadająca o problemach młodej dziewczyny, która stara się żyć zgodnie $\mathrm{z}$ bardzo tradycyjnymi zasadami panującymi w jej rodzinie ${ }^{55}$. Z kolei powieść Suhaila und die Suche nach dem Licht (Suahila i poszukiwanie światła) ${ }^{56}$ to „duchowa podróż do Mekki z czasów Proroka" ${ }^{57}$. Główna bohaterka ulega wypadkowi. Będąc w śpiączce, przenosi się w czasie i poznaje mężczyznę żyjącego w świętym mieście islamu. Ten obcy świat z czasem staje się jej bliski. Ostatecznie staje przed dylematem, czy wrócić do swojego dawnego życia, czy pozostać w przeszłości.

Literatura muzułmańska tworzona jest także w języku angielskim, często przez młodych czy też początkujących pisarzy, i skierowana do młodego odbiorcy ${ }^{58}$. Powstał także

\footnotetext{
52 Por. M. M. Dziekan, op. cit., s. 22.

${ }^{53}$ Al-Mausu'a at-tarichijja ar-rasmijja li-dżama'at al-ichwan al-muslimin http://www.ikhwanwiki.com/index.php?title=محمد الحسناوي. Data dostępu: 15 XII 2012.

${ }_{54}$ M. M. Dziekan wymienia dzieła takich autorów, jak Selim Chazbijewicz, Piotr Ibrahim Kalwas, Musa Czachorowski. M. M. Dziekan, op. cit., s. 25.

55 S. Aded, Noura, Berlin 2011.

56 I. Mohamed, Suhaila und die Suche nach dem Licht, Berlin 2011.

57 Http://iqra-verlag.net/Romane/Suhaila-und-die-Suche-nach-dem-Licht.html.

58 Por. M. M. Dziekan, op. cit., s. 25.
} 
portal internetowy Muslim Youth Musings, który propaguje aktywność literacką wśród młodych muzułmanów. Intencją jego twórców, przeważnie studentów, jest tworzenie: „a literary magazine committed to inspiring the Ummah through quality Islamic literature authored by Muslim youth across the world" 59 . Nowa literatura jest promowana w środowiskach muzułmańskich na Zachodzie, wśród dzieci imigrantów, nieznających języka kraju, z którego wyemigrowali ich przodkowie oraz konwertytów.

Specyficzny typ literatury muzułmańskiej, z pogranicza dwóch światów, przedstawia twórczość arabskich autorów piszących w językach europejskich, najczęściej angielskim lub francuskim. Klasyfikacja tych utworów nie jest jednoznaczna. Za przykład może posłużyć tutaj dorobek sudańskiej pisarki Lajli Abu al-Ala (Leili Abouleli), laureatki wielu nagród literackich. Jej powieści, takie jak The Translator (Tłumaczka) ${ }^{60}$, Minaret (Minaret) ${ }^{61}$, Lyrics Alley (Aleja lirycznych pieśni) ${ }^{62}$, zostały napisane w języku angielskim i wydane w Nowym Jorku. Abu al-Ala studiowała i mieszkała na Zachodzie, obecnie jednak żyje w Katarze. Szczególną uwagę zwraca powieść Minaret, którą J. M. Coetzee określił jako „historię miłości i wiary, napisaną z powściągliwością, dzięki której jeszcze bardziej porusza" ${ }^{3}$. Powieść opowiada o przemianie kobiety pochodzącej z zamożnej rodziny, która beztroskie lata dzieciństwa spędziła w Sudanie. W wyniku przewrotu rodzina traci majątek, po aresztowaniu ojca Nadżwa wraz z matką i bratem ucieka do Wielkiej Brytanii. Tam po wielu kryzysach, znajduje oparcie w środowisku praktykujących muzułmanów. Po śmierci matki i aresztowaniu brata, zakłada chustę i zaczyna zarabiać na utrzymanie jako gosposia w domach zamożnych emigrantów. Pobożność Nadżwy sprawia, że nawiązuje więź z dużo młodszym od siebie i zaangażowanym religijnie bratem pracodawczyni. Duchowe porozumienie stopniowo przeradza się we wzajemną fascynację. Kobieta decyduje się zrezygnować z tego uczucia dla dobra chłopca i tym samym traci pracę.

Rosnąca popularność al-adab al-islami sprawia, że stała się ona w ciągu ostatnich trzech dekad przedmiotem badań, tematem rozpraw akademickich i opracowań krytycznych w świecie arabskim ${ }^{64}$. Zachodnich opracowań na temat literatury muzułmańskiej jest bardzo niewiele. Do nielicznych na Zachodzie badaczy należy Johann Ch. Bürgel. Analizując literaturę muzułmańską, definiuje ją następująco:

Sama nazwa adab islami przez analogię przypomina nazwę powstałego w średniowiecznej medycynie kierunku określanego jako medycyna muzułmańska lub medycyna proroka (tibb islami, tibb nabawi). Odróżnienie to miało na celu wyparcie odziedziczonej po Grekach medycyny Galena, która dla ówczesnych fundamentalistów była tworem pogańskim. Proces zdaje się logiczny i zgodny z koncepcją, że historię kultury muzułmańskiej należy postrzegać jako niekończącą się historię islamizacji zjawisk kulturowych, których pogańska moc powinna zostać podporządkowana boskiej wszechmocy. Zachodnia, jak również pro-zachodnia literatura we własnych

$59 \mathrm{Http} / / /$ www.muslimyouthmusings.com. Data dostępu: 15 XII 2012.

60 L. Aboulela, The Translator, New York 1999. Polski przekład: L. Aboulela, Tłumaczka, tłum. A. Zdziemborska, Warszawa 2011

${ }^{61}$ L. Aboulela, Minaret, New York 2005. Polski przekład: L. Aboulela, Minaret, tłum. A. Zdziemborska, Warszawa 2010.

62 L. Aboulela, Lyrics Alley, New York 2011. 2001. Polski przekład: L. Aboulela, Arabska pieśń, tłum. J. Urban, Warszawa 2011.

${ }_{63}$ Cytat umieszczony na okładce polskiego wydania powieści Minaret.

${ }^{64}$ Spis rozpraw poświęconych teorii muzułmańskiej w literaturze podaje Dż. al-Hamdawi, op. cit. 
krajach uważana jest przez tych autorów za skorumpowaną i zepsutą moralnie. Dlatego też nadszedł czas, aby przeciwstawić jej muzułmańskie wartości ${ }^{65}$.

Prezentowany przez J. Ch. Bürgela pogląd znajduje potwierdzenie w prezentowanej przez niektórych badaczy koncepcji „współczesnej szu’ubijii”. Szu’ubijja (nacjonalizm) to nazwa ruchu, którego celem była walka pomiędzy Arabami a Persami o polityczną i kulturalną supremację w kalifacie abbasydzkim w VIII i IX wieku ${ }^{66}$. Na niwie literackiej linia podziału pomiędzy zwolennikami a przeciwnikami tradycji nie pokrywała się z podziałem narodowościowym. Wśród modernistów byli rdzenni Arabowie, a wśród tradycjonalistów mawali ${ }^{67}$.

Bakri Szajch Amin, porównując dawną i współczesną szu'ubijję, stwierdza, że dawna szu'ubijja była reakcją na rządy, które lekceważyły i pomijały pierwiastek niearabski oraz traktowały go w sposób niesprawiedliwy i niezgodny z islamem. Rządzący sprzeciwiali się nakazowi Koranu i sunny, który każe traktować wszystkich muzułmanów w ten sam sposób. Władcy umajjadzcy i abbasydzcy odeszli od nauk Proroka, dzieląc społeczeństwo na klasy i dyskryminując nie-Arabów. Stąd też dawna szu’ubijja miała swoje źródła w dominacji arabskiej, religii irańskiej oraz systemie rządów. Natomiast obecnie szu’ubijja jest zjawiskiem o wiele bardziej skomplikowanym. Pierwsza szu'ubijja miała ograniczony zasięg i dotyczyła niewielkiej grupy, zas współczesna ma ogólnoświatowy zasięg. Z jednej strony zachodni intelektualiści prezentują muzułmanina oraz „muzułmańską” umysłowość jako ograniczoną, a źródła owego ograniczenia dopatrują się w religii. Z drugiej strony sami muzułmanie, jeżeli nie odrzucają zachodnich wzorców zalewających świat muzułmański i dominujących we wszystkich dziedzinach działalności kulturalnej, przyczyniają się do utrwalania tego wizerunku ${ }^{68}$.

Al-Kajlani ubolewa nad faktem, że współczesny muzułmanin więcej wie o historii Europy i świata niż o cywilizacji muzułmańskiej. Według niego uniwersytety w krajach arabskich bazują na filarach myśli europejskiej, ignorując prawie zupełnie własne źródła filozofii, ekonomii czy prawa. „Czegoż więcej mogą chcieć nasi wrogowie? - pyta Al-Kajlani. „Sami własnymi rękami realizujemy ich plany. Sami burzymy swoje twierdze od wewnątrz. Dlatego nie ma innej alternatywy, jak tylko stworzyć nowe podstawy wychowania i nauczania w krajach muzułmańskich, które będą miały za zadanie ukształtowanie nowego pokolenia. Te podstawy powinny opierać się na myśli muzułmańskiej, jej szkołach koranicznych oraz literaturze proroka"69. Muzułmanie, sięgając do własnej tradycji, powinni bronić się przed napływem zachodnich wzorców. Bardzo ważnym narzędziem w tej walce jest literatura.

Zarówno teoria, jak i literatura muzułmańska ma wielu krytyków w samym świecie arabskim. Zarzuca się jej brak wartości, tanie moralizatorstwo, propagowanie fundamentalistycznych idei i wspieranie wrogiego nastawienia do „nie-muzułmanów”.

Do grona krytyków zalicza się także wspomniany już J. Ch. Bürgel, który określa literaturę muzułmańską jako tubę propagandową różnego rodzaju ruchów, za którymi jednoznacznie stoją środowiska fundamentalistyczne, stowarzyszenia i mistyczne bractwa,

\footnotetext{
65 J. Ch. Bürgel, op. cit., s. 823.

66 Por. J. Bielawski, Klasyczna literatura arabska, Warszawa 1995, s. 111-112 i 136.

67 Mawali - klienci, niearabscy mieszkańcy kalifatu, którzy przeszli na islam.

68 B. Szajch Amin, Bajna szu'ubijjat al-kudama wa-szu'ubijjat al-mua'asirin, http://adabislami.org/magazine/2011/11/451/35 Data dostępu: 15 XII 2012.

69 N. al-Kajlani, Ada al-islamijja, http://www.odabasham.net/show.php?sid=33188. Data dostępu: 15 XII 2012.
} 
które dysponują własnymi wydawnictwami oraz gazetami, jak np. nakszbandijja. Ten niemiecki islamista, znający świetnie literaturę perską i turecką, w swojej analizie skupia się na utworach pisanych w języku tureckim. Nagrodzonego przez Światową Ligę Literatury Muzułmańskiej tureckiego pisarza ostro krytykuje, odmawiając jego powieści wartości artystycznych: „Widać wyraźnie, że autorowi przypowieści brak nawet krzty krytycyzmu. Dla niego są tylko dobrzy i źli, którzy chcą zniszczyć spokój dobrych, a także są sprawcami całego nieszczęścia i dlatego zostają zniszczeni”70. O Nadżibie Al-Kajlanim jedynie wspomina, określając go jako „znaczącego apologetę i teoretyka literatury muzułmańskiej”. Z twórczości w języku arabskim nadmienia o „utopijnym dramacie” zatytułowanym Al-Bud al-chamis (Piąty wymiar, 1985), który został napisany w kairskim więzieniu przez członka Braci Muzulmańskich Ahmada Ra’ifa. Utwór ten na tle „taniej propagandy” wypada, zdaniem Bürgela, tylko odrobinę lepiej dzięki bardziej pomysłowej akcji, natomiast, podobnie jak dzieła tureckie, prezentuje „nierealistyczne stereotypy”. Badacz ten nie dostrzega w analizowanych powieściach artystycznych wartości, o których pisał Imad ad-Din Chalil, a jedynie cele, które „literatura muzułmańska realizuje «pretendując» do miana czegoś na kształt littérature engagée”. Podkreśla jednak, że cieszy się ona dużą poczytnością i zaspokaja „potrzeby czytelnika, którym nie jest w stanie sprostać oficjalna, oparta na zachodnich wzorcach literatura" ${ }^{71}$.

Wprawdzie nie można uważać literatury muzułmańskiej za nurt rozwiązujący wszelkie problemy, z którymi boryka się literatura i ogólnie sztuka, tak jak tego chcą jej najbardziej gorący apologeci ${ }^{72}$, jednak J. Ch. Bürgel zdaje się tutaj stawać po drugiej stronie ruchu szu'ubijja, czyli reprezentuje pogląd, że jeśli literatura jest niezgodna z europejską estetyką, nie może być „piękna”. Wrzuca wszystkie utwory reprezentujące muzulmańską perspektywę do worka „taniej propagandy”. Być może jednak należałoby przy analizowaniu literatury muzułmańskiej przyjąć muzułmańskie kryteria wypracowane przez muzułmańskich badaczy. Zgodnie z twierdzeniem Chalila bardzo trudno jest pisać dobrą zaangażowaną literaturę i nie każda powieść czy opowiadanie jest w stanie sprostać wymogom jej stawianym.

Jak pisze M. M. Dziekan, muzułmańska literatura oraz muzułmańskie teorie literackie stanowią ważną, lecz prawie nieznaną część współczesnej arabskiej kultury literackiej, dlatego też powinny one stać się przedmiotem badań islamistów i arabistów, i odnaleźć w literaturze arabskiej należne im miejsce ${ }^{73}$.

\footnotetext{
70 J. Ch. Bürgel, op. cit., s. 824-825.

71 Ibidem.

${ }_{72}$ Dż. al-Hamdawi, op. cit.

${ }^{73}$ M. M. Dziekan, op. cit., s. 17.
} 